\title{
Zooplankton abundance and diversity of fishponds exposed to different management practices
}

\author{
A.A. ADEDEJI ${ }^{1 *}$, I.F. ADENIYI ${ }^{1}$ and H. MASUNDIRE ${ }^{2}$ \\ ${ }^{I}$ Department of Zoology, Obafemi Awolowo University, Ile-Ife, Nigeria. \\ ${ }^{2}$ Department of Biological Sciences, University of Botswana, Gaborone, Botswana. \\ *Corresponding author,E-mail: bbkadedeji@yahoo.com; bbkadedeji@oauife.edu.ng
}

\begin{abstract}
The taxonomic composition and community structure of zooplankton faunae of selected earthen fishponds in Ife North Local Government Area of Osun State, Nigeria were investigated for a period of two years sampling every other month. The study was based on three sets of fishponds with regards to fertilization practice and water flow regime. These include non flow-through ponds that received organic and inorganic fertilizers (FNF); flow-through ponds that received organic and inorganic fertilizers (FF) and unfertilized flowthrough ponds. The zooplankton fauna of the fishponds comprised of 81 species belonging to three phyla namely Rotifera (62 species belonging to 16 families and two orders), Arthropoda ( 6 cladocerans, 2 copepods, 6 ostracods, 4 insecta and one arachnid species) and Protozoa which was represented by only one species. Zooplankton species richness indices were generally higher in the flow-through ponds than in the non flow through ponds with some species occurring only in the fertilized flow-through ponds. The flow-through pond had the highest number of species 54, while the least number of species 37 was recorded from the non flowthrough pond. The fertilized non-flow-through ponds also had the highest mean abundance of $36762 \pm 56162$ $\mathrm{ind} / \mathrm{m}^{3}$, followed by fertilized flow-through ponds $\left(34346 \pm 40784 \mathrm{ind} / \mathrm{m}^{3}\right)$ and non-fertilized flow-through ponds $\left(16006 \pm 41263 \mathrm{ind} / \mathrm{m}^{3}\right)$ descending order. The means in zooplankton abundance among the ponds were, however, not statistically significant. The fertilized ponds supported zooplankton abundance while continuous water flow as observed in the flow-through had direct influence on diversity and species richness. Hence to achieve the desired effect of pond fertilization on its primary productivity, this must be accompanied by adequate water flowage especially in shallow fish ponds.
\end{abstract}

(c) 2013 International Formulae Group. All rights reserved.

Keywords: Zooplankton, community structure, diversity, fish ponds, fertilization.

\section{INTRODUCTION}

Zooplankton play important roles in the energy and material transfer in waterbodies as the consumers of phytoplankton (Welch, 1992). Garesoupe (1982) and Kibria et al. (1997) revealed that zooplankton are a valuable source of protein, amino acids, lipids, fatty acids and essential minerals and enzymes needed by aquatic organisms for effective normal growth and survival. Several studies have also indicated improved performance of fish larvae fed natural indigenous live zooplankton (Lubzen, 1987; Ovie et al., 1993; Adeyemo et al., 1994) while according to Alam and Cheah (1993), both live and frozen 
zooplankton have also been used in commercial and experimental aquaculture.

Fertilization of ponds to enhance alga growth and produce zooplankton suitable for larval fish is a common practice in Nigeria. Nutrient increase as a result of pond fertilization has direct impact on the plankton community and ultimately the fish biomass (Sipauba-Tavares et al., 2011). The plankton biomass and composition in ponds (shallow waters) fluctuate as a reaction to several interacting driving force which may include polymixis, water level changes, weather conditions, nutrient loading and feeding management ( Borics et al., 2000). Several studies have revealed that both quality and quantity abundance of plankton communities in fishponds vary from location to location and pond to pond within the same location even under similar ecological conditions (Boyd, 1982; Chowdhury and Mamun, 2006; Bhuiyan et al., 2008). Factors that affect plankton distribution and abundance include season, physical and chemical parameters, water movement, soil, and biological factors (Davies et al., 2009).

Therefore, the study aimed at evaluating zooplankton taxonomic composition, biomass and community structure under different pond management over a period of two years to determine the effect of pond fertilization and water flowage on their community structure.

\section{Area of study}

The fish ponds investigated in this study belong to Niger Feeds and Agricultural Operations Limited (NIFAGOL), one of the few major commercial fish farms in Osun State, Nigeria. The fish farm is located in Yakoyo - Origbo in the northern part of Ife North Local Government Area (LGA), Osun State, Nigeria. The LGA is located roughly between Latitudes $07^{0} 25^{\prime}-07^{0} 40^{\prime} \mathrm{N}$ and Longitudes $004^{0} 25^{\prime}-004^{0} 30^{\prime} \mathrm{E}$, on a general elevation range of $250-265 \mathrm{~m}$ above mean sea level. It comprises 18 ponds of varying sizes, each rectangular in outline and about $2.5 \mathrm{~m}$ deep. Only ten out of the 18 ponds were in use during the present study. Water is supplied into these ponds from a nearby reservoir with a surface area of $20,000 \mathrm{~m}^{2}(2$ hectares).

The aquaculture system being practised in the farm is the semi-intensive type. Four of out of the ten in use culture ponds were being fertilized with both organic fertilizers (chicken droppings and cow dung) and inorganic fertilizers (NPK). Supplemental feeding was also given in small quantity to the stocked fish. The water retention period for fertilized ponds was 6 months while the unfertilized ponds were left undrained. These unfertilized ponds were open with water flowing through. The fish stock density for all the ponds was 3 fish $/ \mathrm{m}^{2}$. The fish were fed twice daily and their feeds included locally made pellets (made from mixture of maize, soybeans, fishmeal, millet, palm kernel cake, groundnut cake and palm kernel oil) and Brewer's waste. The fish being reared in the pond was Clarias gariepinus.

\section{MATERIALS AND METHODS}

Of the eighteen ponds in NIFAGOL fish farm, only ten ponds were operational during the present study. Water samples were collected from six of these ten ponds every other month over a period of two years from February 2006 to February 2008. For the purpose of this study, the six ponds were grouped into three sets with regard to fertilization (fertilizer treatment) and water flowage based on the existing culture practices. The first sets of two ponds, fertilized non flow-through ponds (FNF) received organic and inorganic fertilizers and were non flow-through. The second sets of two ponds, fertilized flow-through ponds (FF) received organic and inorganic fertilizers as FNF but were flow-through ponds. The third sets of two ponds, not fertilized flow-through (NFF) received no fertilizer but were flowthrough ponds.

Thirty litres of water collected from each pond was filtered and concentrated to 20 $\mathrm{mL}$ using a $45 \mu \mathrm{m}$ plankton net. The plankton concentrate samples were preserved in $5 \%$ 
formalin to which was added two drops of Lugol solution for quantitative and qualitative examination. Planktonic enumeration were done by introducing $1 \mathrm{~mL}$ of the preserved concentrate plankton samples into a SedwickRafter counting chamber for examination through an Olympus $\mathrm{BH} 2$ Microscope. Planktonic identification was done to specific levels according to Edmondson (1959), Adeniyi (1978), Akinbuwa and Adeniyi (1991), Seger et al. (1991, 1993), Akinbuwa, (1999) and Fernando (2002). The variation in ponds and seasonal abundance of zooplankton were analyzed using SPSS16 for windows (Statistical Software package, SPSS Inc.); PAST and SYSTAT 13. The analysis involved descriptive statistics and multivariate statistics ( $t$ test, Kruskal-Wallis Test and Andrews' Fourier plot). The various indices of community structure (species richness, diversity and evenness indices) were all calculated in accordance with the procedures of Ludwig and Reynolds (1988). The relationships between the different ponds investigated based on zooplankton abundance were established using cluster analysis (single linkage method) according to Hedges (1971).

\section{RESULTS}

\section{Taxa composition}

The zooplankton fauna of the fishponds comprised of 81 species belonging to three phyla. There were 62 species of rotifers belonging to 16 families and two orders. The arthropods comprised of 6 cladocerans, 2 copepods, 6 ostracods, 4 insects and one arachnid species. A total of 24 species were common to all the ponds while some were restricted in distribution. The restricted species included Branchionus dimidiatus inermis and Notholca squamula found only in fertilized flow-through ponds; Keratella taurocephala, Lecane ludwigii and Macrochaetus collinsi brazilensis occurred only in non-fertilized flow-through ponds. Of the 24 organisms found to occur most frequently, 20 of them were rotifers while the remaining four species were Diaphanosoma brachyurum, Mesocyclops edax, Cyclocypris serena and Chironomus sp larva. Some species showed specific seasonal occurrence, these include Filinia pejleri, Brachionus dimidiatus inermis, Keratella taurocephala, Lepadella patella similis, Albertia sp, Lecane ungulata, Elosa worrali, Trichocerca bcristata, Daphnia longiremis, Eucypris fuscatus, Corethrella sp, Hesperocorixa obliqua and Hydracaina sp which were recorded only during the rainy season. While Horaella brehmi, Brachionus budapentinensis, Notholca squamula, Lecane ludwigii, Lecane lunaris, Lecane monostyla copies, Macrochaetus collinsi braziliensis and Belostoma sp occurred only during the dry season.

Distribution pattern, abundance and community structure

The total number of species per pond varied from 37 to 54 . The flow-through pond had the highest number of species, 54 while the least number of species, 37 was recorded from the non flow-through pond. On the average, more species were recorded during the rainy season (with a mean of 41 species per pond) than during the dry season (with a mean of 37 species per pond). This trend was applicable to all the ponds except the fertilized flow-through ponds where the number of species recorded during the dry season was slightly higher $(P \geq 0.05)$ than the number for the rainy season. This was evident with the increase in total number of organisms recorded for each species from these ponds except copepods and cladocerans (Figure 1).

Rotifers were most abundant in all the ponds for both season, followed by copepods while no species of the class insect was recorded from the fertilized non flow-through ponds during the dry season (Figure 1). Trichocerca cylindrica, with the highest number of individual per $\mathrm{m}^{3}$ (188667 ind/ $\mathrm{m}^{3}$ ) as well as the maximum total number of organisms per $\mathrm{m}^{3}$ (210644 ind/ $\mathrm{m}^{3}$ ) was recorded in the fertilized non-flow-through pond during the onset of rainy season (April, 2007) and late dry season (February, 2007) respectively. The fertilized non-flow-through 
ponds also had the highest mean abundance of $36762 \pm 56162 \mathrm{ind} / \mathrm{m}^{3}$, followed by fertilized flow-through ponds $\left(34346 \pm 40784 \mathrm{ind} / \mathrm{m}^{3}\right)$ and non-fertilized flow-through ponds (16006 $\pm 41263 \mathrm{ind} / \mathrm{m}^{3}$ ) descending order. The mean total abundances among the ponds were not significantly different. However the zooplankton fauna in the ponds were more abundant during the dry season than during the rainy season (Figure 1). The overall difference in mean abundance for the respective species was not significant except for Cyclops scutifer $(\mathrm{P}<0.05)$. The species with the highest abundance during the rainy season was Trichocerca cylindrica $\left(1.02 \times 10^{4}\right.$ $\pm 3.67 \times 10^{4} \mathrm{ind} / \mathrm{m}^{3}$ ) while Anuraeopsis fissa had the highest value during the dry season $\left(8008.7 \pm 1.30\right.$ x $\left.10^{4} \mathrm{ind} / \mathrm{m}^{3}\right)$. Brachionus dimidiatus inermis, Keratella taurocephala, Lecane ungulata, Trichocerca bicristata, Daphnia longiremis, as well as Hydracarina each had relatively low abundance during the dry season while Horaella brehmi, Brachionus budapestinensis, Notholca squamula, Lecane ludwigii, Lecane lunaris, Lecane monostyla copies, Belostoma sp were characterised by low abundance during the rainy season.

Zooplankton species richness indices were generally higher in the flow-through ponds than in the non flow through ponds (Table 1), with Margalef index $\left(\mathrm{R}_{1}\right)$ values ranging from 3.25 (non flow-through pond) to 4.42 (flow-through pond). This suggests that the flow-through ponds were much richer in species than the non flow-through ponds. The zooplankton population in the fertilized flowthrough ponds were more diverse than that of other investigated ponds with Simpson's diversity index of 0.11 and 0.14 and highest number of very abundant species of 8 and 10 species respectively according to Hill's Second diversity index of number $\left(\mathrm{N}_{2}\right)$. These accounted for $84 \%$ and $87 \%$ of the recorded abundance in the respective ponds. The number of abundant species (based on Hill's first diversity number) was also quite high for the fertilized flow through ponds. Diversity was very low in pond 1 (fertilized non flow- through pond) and pond 5 ( non fertilized flow-through pond) with about 3 to 4 species accounting for $79 \%$, and $92 \%$, of the recorded abundance in the ponds respectively.

The Hill's Evenness indices $\left(\mathrm{E}_{4}\right.$ and $\left.\mathrm{E}_{5}\right)$ were above 0.40 for most of the ponds except Pond 1, thus the relative abundances of species in the pond did not totally diverge from evenness and this also confirmed the dominance of few abundant species in Pond 1.

\section{Inter-pond relationship}

The Andrews' Fourier plot based on the zooplankton abundance in the ponds revealed that the zooplankton distribution among the ponds were quite different over the period of study (Figure 2). The non-fertilized flow-through ponds and the fertilized nonflow-through ponds were however found to have some similarity in distribution of zooplankton based on the cluster analysis of the Morisita similarity index (based on mean abundance of each zooplankton species) between the investigated fish ponds (Figure 3 ). The clusters were found to be based on the number and abundance of the species that these ponds have in common. The fertilized flow-through pond was found to be distinct having seven zooplankton species (Brachionus dimidiatus inermis, Notholca squamula, Euchlanis dilatata, Euchlanis dilatata macrura, Dicranophorus lutkeni, lecane monostyla copies and Belostoma $\mathrm{sp}$ ) which were not found in other ponds.

Using Kruskal-Wallis Test and DwassSteel-Chritchlow-Fligner Test for all pairwise comparison also based on zooplankton abundance, 72 species showed highly significant variations $(\mathrm{P} \leq 0.001)$ in abundance among the ponds studied. Of which 32 species accounted for highly significant differences between the fertilized ponds and non-fertilized ponds; 26 species varied significantly between the fertilized flow-through and other ponds while the significant differences between the flowthrough and non-flow-through ponds were due to 14 species. 
Table 1: Zooplankton richness, diversity and evenness of the investigated ponds.

\begin{tabular}{|c|c|c|c|c|c|c|}
\hline \multirow{3}{*}{ Index } & \multicolumn{6}{|c|}{ Waterbodies } \\
\hline & \multicolumn{2}{|c|}{ FNF } & \multicolumn{2}{|c|}{ FF } & \multicolumn{2}{|c|}{ NFF } \\
\hline & Pond 1 & Pond 2 & Pond 3 & Pond 4 & Pond 5 & Pond 6 \\
\hline Total number of species (S) & 50 & 37 & 50 & 55 & 51 & 55 \\
\hline Margalef index $\left(\mathrm{R}_{1}\right)$ & 3.86 & 3.25 & 3.70 & 4.33 & 3.72 & 4.42 \\
\hline \multicolumn{7}{|l|}{ Diversity Indices } \\
\hline Simpson index $(\lambda)$ & 0.35 & 0.09 & 0.14 & 0.11 & 0.23 & 0.18 \\
\hline Hill's First Diversity Number $\left(\mathrm{N}_{1}\right)$ & 5.71 & 15.48 & 10.89 & 12.96 & 5.96 & 9.70 \\
\hline Hill's Second Diversity Number $\left(\mathrm{N}_{2}\right)$ & 2.88 & 11.47 & 7.27 & 9.32 & 4.26 & 5.57 \\
\hline Percentage accounted for by abundant species (\%) & 79 & 88 & 84 & 87 & 92 & 83 \\
\hline \multicolumn{7}{|l|}{ Evenness Indices } \\
\hline $\operatorname{Hill}\left(\mathrm{E}_{4}\right)$ & 0.51 & 0.74 & 0.67 & 0.72 & 0.72 & 0.57 \\
\hline Modified Hill $\left(\mathrm{E}_{5}\right)$ & 0.40 & 0.72 & 0.63 & 0.70 & 0.66 & 0.52 \\
\hline
\end{tabular}


A.A.ADEDEJI et al. / Int. J. Biol. Chem. Sci. 7(2): 631-640, 2013

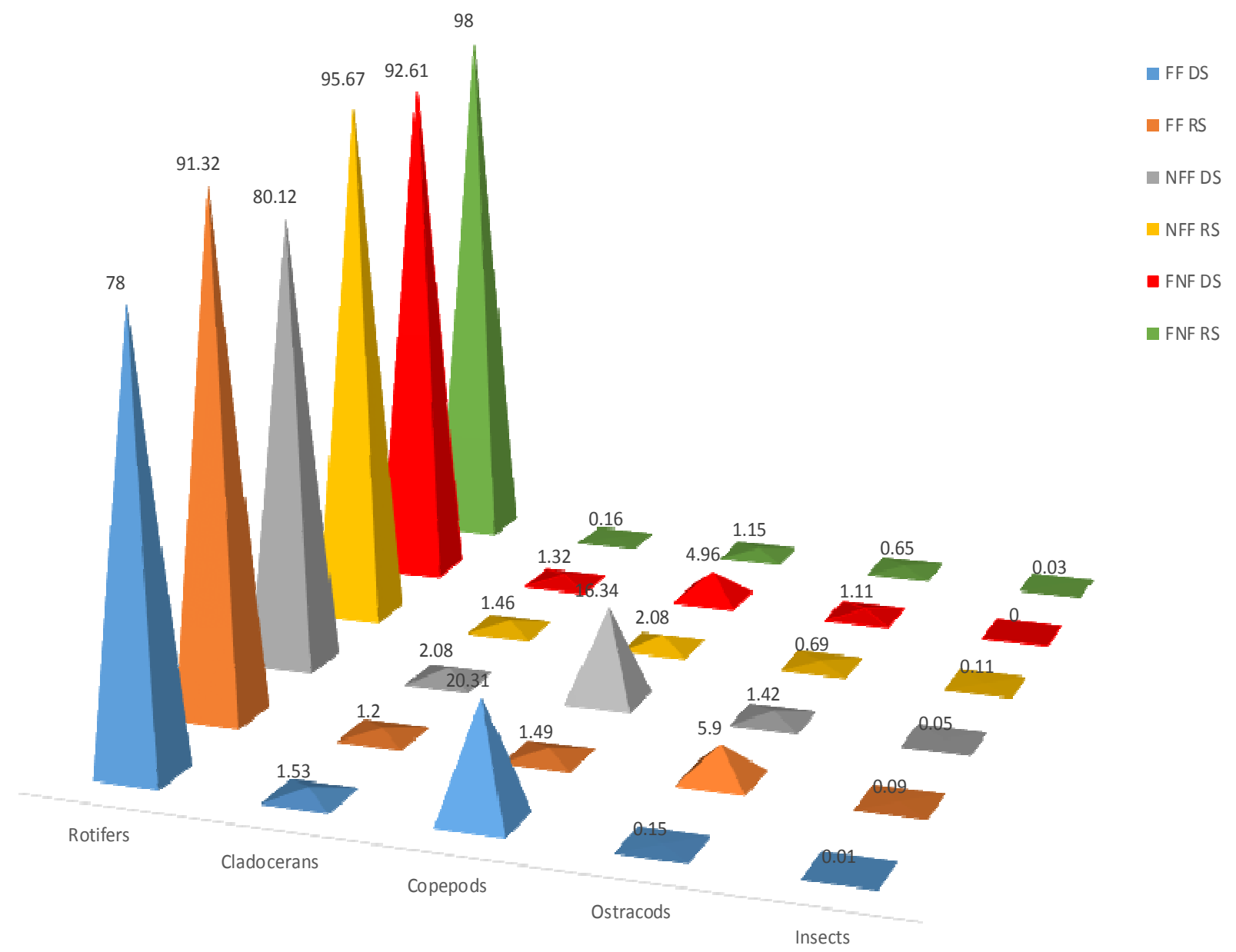

Figure: Relative abundance (\%) of zooplankton groups in the fish ponds (FF, FNF and NFF) during the stuclied period. 
A.A.ADEDEJI et al. / Int. J. Biol. Chem. Sci. 7(2): 631-640, 2013
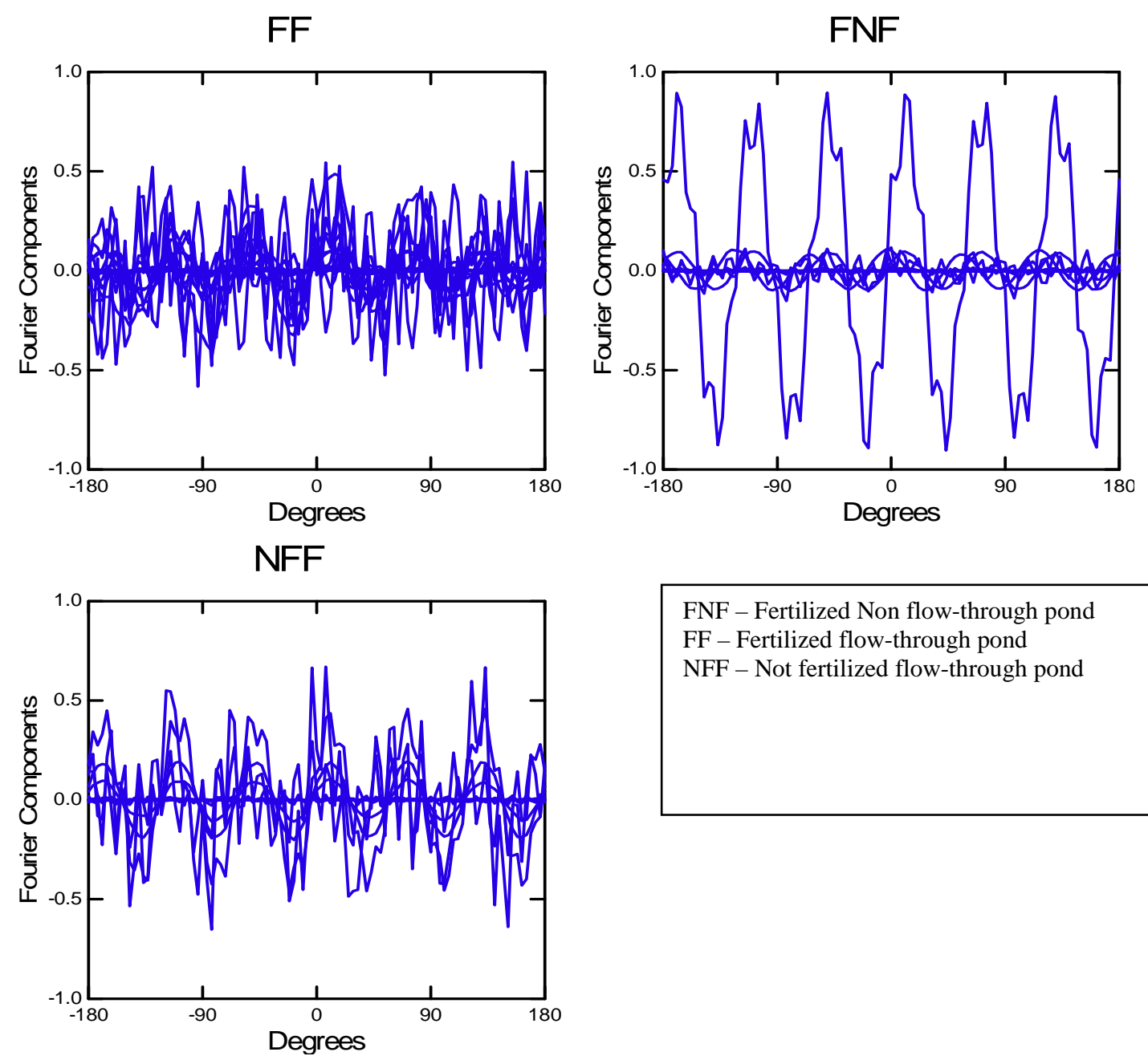

$$
\begin{aligned}
& \text { FNF - Fertilized Non flow-through pond } \\
& \text { FF - Fertilized flow-through pond } \\
& \text { NFF - Not fertilized flow-through pond }
\end{aligned}
$$

Figure 2: Andrews Fourier Plot based on the zooplankton abundance in the ponds through the period of study. 


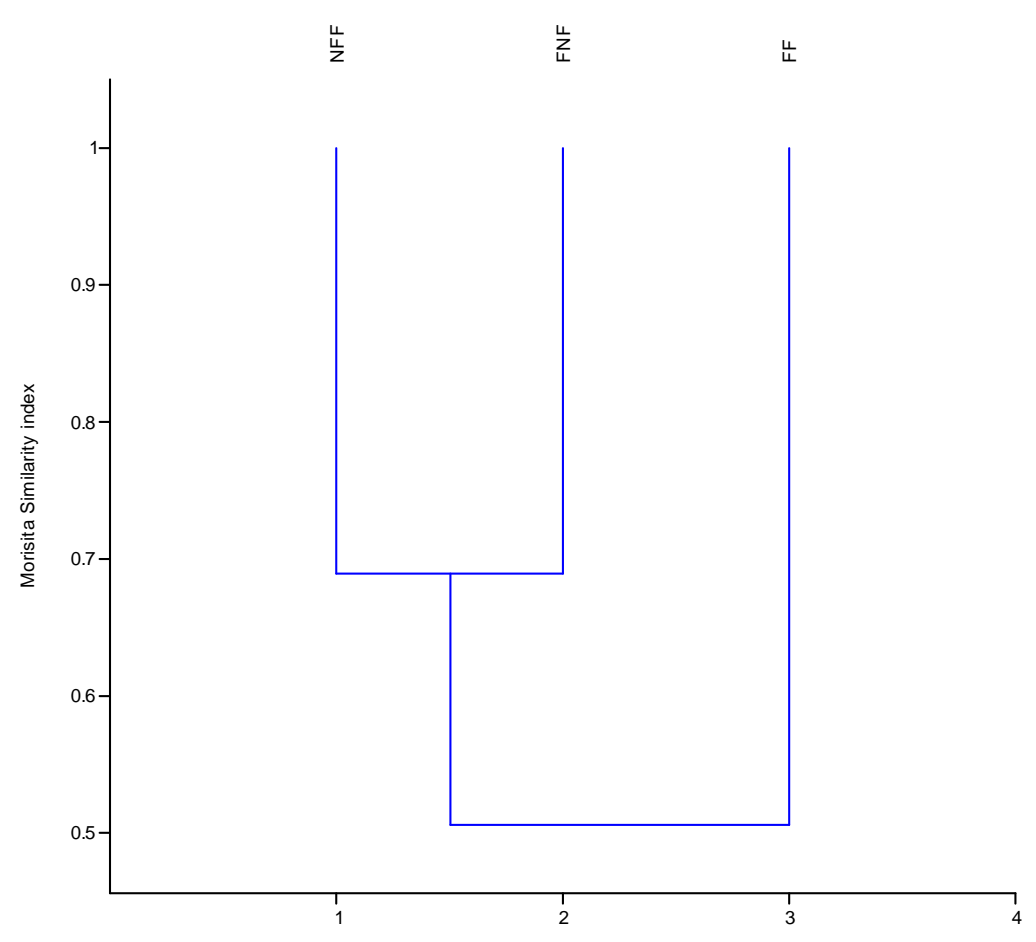

Figure 3: Cluster analysis showing the relationship between the investigated ponds based on the Zooplankton species occurrence and abundance.

\section{DISCUSSION}

The observed significant and non-significant differences in zooplankton composition, distribution pattern, abundance and community structure between the studied ponds subjected to different pond management; further proven the fact that plankton distribution and abundance are affected by season, physical and chemical parameters, water movement, soil and biological factors (Davies et al., 2009). The water movement was observed to influence species richness and diversity of zooplankton been evident in the number of species found in the flow-through ponds which were more than those found in the non- flowthrough ponds. The restriction in distribution of some species to the flow-through ponds further revealed that continuous water flow have great impact on the diversity and species richness of fish ponds (SipaúbaTavares et al., 2011). Moreover, the use of organic fertilizer has been known to decrease species richness and consequently favoured the occurrence of opportunist species while continuous water flow influences diversity of species (Vega et al., 2007).

The combined use of organic and inorganic fertilizer is known to have direct impact on the plankton community structure (Sipaúba-Tavares et al., 2011) by promoting both the autotrophic and heterotrophic organisms in the ponds. Organic fertilization is also known to promote the growth of smaller sized zooplankton especially the rotifers (Okojin and Obi, 1999) as well as other micro-zooplankton such as protozoans and copepod nauplii (Pinto-Coelho et al., 2005) which usually dominate eutrophic waters. This explains the abundance of rotifer group followed by the copepods throughout the period of study. High Rotifera density has been associated with the capacity of the organisms to adapt themselves quickly to environmental disruption and perturbation especially in physicochemically unstable systems such as fish ponds (Sipaúba-Tavares and Colus, 1997). Moreover rotifer abundance could be attributed to decline in crustacean population as these were being preyed upon by larval fish in the ponds. As well, rotifers have the ability to reproduce rapidly via parthenogenesis (Geiger, 1983; Geiger et al., 1985; and Roche and Rocha, 2005). Among the rotifers, members of the family Brachionidae were the most dominant, as is typical of West African freshwater ecosystems (Egborge, 1981; Egborge and Chigbu, 1988; Akinbuwa and Adeniyi, 1991).

Highest mean zooplankton abundance recorded for the fertilized ponds also reveals the role of pond fertilization in maintaining the phytoplankton and zooplankton populations in rearing ponds (Afzal et al., 2007). While the level of abundance of zooplankton observed in the non-fertilized ponds could be attributed to the fish culturing processes being practiced during the period of study. As management procedures such as stocking 
densities, feeding, and sediment removal aside fertilization of fish ponds directly affect the ecological processes developing in the water column of ponds (Sipaúba-Tavares et al., 2011). They further explained that shallowness of fish ponds and constant load of nutrients from feed, fertilizing and fish waste contributes to algal growth and development of zooplankton organisms.

During the rainy season, the ponds were found to be richer qualitatively and quantitatively in zooplankton fauna than during the dry season. High flood discharge into the ponds results in many organisms being scoured from the riverbed or dislodged from the littoral vegetation to enrich the ponds (Adeniyi and Adedeji, 2007). The findings of Koli and Muley (2012) was, however, contrary as a negative correlation with rainfall was reported for zooplankton abundance in Tulish Reservoir of Kolhapur District India. These variations in plankton distribution and abundance, according to Davies et al. (2009), could be attributed to variations in physical and chemical parameters as well as water movement, soil and biological factors of the waterbody. Cottenie et al. (2001) similarly concluded that zooplankton community structure can be linked to local biotic and abiotic interactions.

The highly significant differences in the distribution of zooplankton among the fish ponds analysed reveals that fertilization of ponds (combined organic and inorganic) and continuous flow of water have direct impact on the zooplankton abundance, diversity and species richness of fish ponds (SipaúbaTavares et al., 2011).

In summary, the fertilized ponds supported zooplankton abundance while continuous water flow as observed in the flow-through had direct influence on diversity and species richness. Hence to achieve the desired effect of pond fertilization on its primary productivity, this must be accompanied by adequate water flowage especially in shallow fish ponds. Therefore, further studies aiming at evaluating the most effective rate of water flow to adequately manage the planktonic population is recommended.

\section{REFERENCES}

Adeniyi IF. 1978. Studies on the physico-chemical factors and the planktonic algae of Lake Kainji. Ph.D. thesis, University of Ife, IIe-Ife, Nigeria, 597 pp.

Adeniyi IF, Adedeji AA. 2007. The Rotifera fauna of Gongola River basin, Northeast Nigeria. Ife Journal of Science, 9(1): 1-16

Adeyemo AA, Oladosu GA, Ayinla OA.1994. Growth and survival of fry of African Catfish species (Clarias gariepinus Burchell, Heterobranchus bidorsals Geoffery and Heteroclarias) reared on
Monia dubia in comparison with other first feed sources. Aquaculture, 119: 41-45.

Afzal M, RAB A, Akhtar N, Khan MF, Qayyum AB. 2007. Effect of organic and inorganic fertilizers on the growth performance of Bighead carp (Aristichthys nobilis) in polyculture system. International Journal of Agriculture \& Biology, 9(6): 931-933.

Akinbuwa O. 1999. The Rotifer fauna and physiochemical condition of Erinle Lake and its major inflows at Ede, Osun State, Nigeria. Ph.D Thesis, Obafemi Awolowo University, Ile-Ife, Nigeria. pp: 330.

Akinbuwa O, Adeniyi IF. 1991. The Rotifera fauna of Opa Reservoir, Nigeria. Journal of African Zoology, 105(5): 383-391.

Alam MJK, Cheah SH. 1993. Use of Moina micrura (De Man) as an Artemia substitute in the production of Macrobrachium roenbergi (De Man) post larva. Aquaculture, 109: 37-49.

Bhuiyan AS, Islam MT, Sharmeen R. 2008. Occurrence and abundance of some copepods in a fish pond in Rajshahi, Bangladesh in relation to the physicochemical conditions. Journal of Bioscience, 16: 115-119.

Borics G, Grigorzky I, Szabo S, Padisak J. 2000. Phytoplankton associations in a small hypertrophic fish pond in the east Hungary during a change from bottom-up to top-down control. Hydrobiologia, 424(1-3): 79-90

Boyd CE. 1982. Water Quality Management of Pond Fish Culture. Elsevier Sci. Pub. Co.: AmsterdamOxford, New York, 318pp.

Chowdhury AH, Mamun AA. 2006. Physico-chemical conditions and plankton population of two fishponds in Khulna. Univ. j. Zool. Rajshahi Univ., 25: 41-44.

Cottenie K, Nuytten N, Michels E, De Meester L. 2001. Zooplankton community structure and environmental conditions in a set of interconnected ponds. Hydrobiologia, 442: 339-350.

Davies OA, Abowei J F N, Otene BB. 2009. Seasonal abundance and distribution of plankton of Minichinda stream, Niger Delta, Nigeria. American Journal of Science Research, 2(2): 20-30.

Edmondson WT. 1959. Freshwater Biology ( $2^{\text {nd }}$ edn). John Wiley and sons, New York; 1248.

Egborge ABM 1981. The composition, seasonal variation and distribution of zooplankton in lake Asejire, Nigeria. Rev. Zool. Africaine, 95: 137-165.

Egborge ABM, Chigbu P. 1988. The rotifers of Ikpoba River, Bendel State, The Nigerian Field, 53: 117 132.

Fernando CH. 2002. A Guide to tropical Freshwater Zooplankton Identification and Impact on Fisheries. Backhuys Publishers: Leiden, The Netherlands, pp 291. 
Garesoupe JF. 1982. Nutritional and antebacterial treatment of live food organisms: the influence on survival, growth rate and weaning success of Turbo maximus. Ann. Zootech., 31: 353-368

Geiger JG. 1983. A review of pond zooplankton production and fertilization for the culture of larval and fingerling striped bass. Aquaculture, 35: 353-369.

Geiger JG, Turner CJ, Fitzmayer KM, Nichols WC. 1985. Feeding habits of Larval and Fingerling striped bass and zooplankton dynamics in fertilized rearing ponds. Prog. Fish-Cult., 47: 213-233.

Gulate RD, Martinez CP, Siewertsen K. 1995. Zooplankton as a compound mineralizing and synthesizing system: Phosphorus excretion. Hydrobiologia, 315: 25 - 37.

Hedges AJ. 1971. Principles of microbial taxonomy. In Micro-Organisms: Function, Form and Environment, Hawker LE, Linton AH (eds); 458478.

Koli KB, Muley DV. 2012. Study of zooplankton diversity and seasonal variation with special reference to physicochemical parameters in Tulshi Reservoir of Kolhapur District (M.S.), India. E-International Scientific Research Journal, 4(1): 38-46.

Kibria G, Nugegoda D, Fairchongh R, Lam P, Bradly A. 1997. Zooplankton, its biochemistry and significance in aquaculture. NAGAICLARM Quarterly, April/June 1997, 8-14.

Lubzen E. 1987. Raising rotifers for use in aquaculture. Hydrobiologia, 147: 245 - 255.

Ludwig JA, Reynolds JF. 1988. Statistical Ecology: A Primer on Methods and Computing. John Wiley and Sons: New York; 85-109.

Okojin VA, Obi AW. 1999. Effects of three fertilizer treatments on zooplankton productivity in plastic tanks. Indian Journal of Animal Science, 69(5): 360-363.

Ovie SI, Adeniji HA, Olowe DI. 1993. Isolation and growth of curve characteristics of a freshwater zooplankton for feeding early larvae and fry stages of fish. Journal of Aqua. Tropical, 8: 181-196.

Pinto-coelho RM, Giani A, Morais Junior CA, Carvalho Junior ER, Bezerra-neto, JF. 2005. The nutritional status of zooplankton in a tropical reservoir: effects of food quality and community structure. Brazilian Journal of Biology, 65(2): 313-324.

Roche KF, Rocha O. 2005. Aspectos de predação por peixes e, lagos e represas, com enfoque na planctivoria. In Ecologia Trófica de Peixes com ênfase na Planctivoria em Ambientes Lênticos de Água Doce no Brasil, Roche KF, Rocha O (eds). São Carlos: Rima; 1-24.

Segers H, Ajayi A0, Chiambeng GY, Chuah HP, Del Castillo M, Directo MG, Luzuriaga De Cruz M, Moreno L, Oliveira-Neto AL, Retnaning Widyastuti Y. 1991. Fourteen rotifer species new to the Belgian fauna, with nomenclatural and taxonomical remarks on some Squatinella species. Belg. J. Zool., 121: 193-201.

Segers H, Nwadiaro CS, Dumont HJ. 1993. Rotifers of some lakes in the floodplain of the River Niger (Imo State Nigeria). II: Fauna/composition and diversity. Hydrobiologia, 250: 63-71.

Sipaúba-Tavares LH, Colus DSO. 1997. Estrutura da comunidade fitoplanctônica e zooplanctônica em dois viveiros de cultivo semi-intensivo de peixes (Jaboticabal, São Paulo, Brasil). Boletim do Laboratório de Hidrobiologia, 10: 51-64.

Sipaúba-Tavares LH, Donadon ARV, Milan RN. 2011. Water quality and plankton populations in an earthen polyculture pond. Braz. J. Biol., 71(4): 845855.

Vega C, Jambrina C, Saja R, Becares E, Fernández C, Fernández, M. 2007. Aspectos limnológicos de estanques para la producción intensiva de tenca (Tirica tinca). Limnética, 26(1): 173-182.

Welch EB. 1992. Ecological Effect of Wastewater: Applied Limnology and Pollutant effect $\left(2^{\text {nd }}\right.$ edn). Chapman and Hall: London, U.K. 